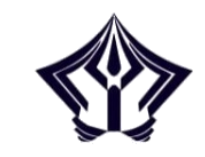

ANFUSINA: JOURNAL OF PSYCHOLOGY

http://ejournal.radenintan.ac.id/index.php/anfusina

DOI: http://dx.doi.org/10.24042/ajp.v2i1.4150

Volume 2, Nomor 1, April Tahun 2019

\title{
Pengaruh Pelatihan Goal Setting \\ Untuk Meningkatkan Motivasi Belajar Pada Mahasiswa
}

\author{
Nugroho Arief Setiawan \\ UIN Raden Intan Lampung \\ nugrohoarief@radenintan.ac.id
}

\begin{abstract}
The purpose of this research was to obtain the effect of goal setting training in improving students motivation to learn. The hypothesis of this study that there were a difference between the level of student learning motivation experiment group with control group were given before and after goal setting training. Students are given goal setting training (experiment group) will increase the learning motivation after treated by goal setting training than students who did not receive goal setting training (control group). Subjects in this study amounted to eighteen for the experimental group and also for the control group. Measuring instruments used to measure the level of learning motivation was learning motivation scale. Experimental design used in this study was Pre-Test Post-Test Control Group Design and the process of determining the subject done randomly. The analysis used was a parametric statistical test models of the Independent Sample $T$ - Test to see differences in learning motivation scores between the experimental group with the control group. The results of the pretest data analysis using Independent Sample T-Test known sig $=0.798(p>0.05)$, and posttest data analysis known sig $=0.000(p<0.005)$. Meanwhile, to see the difference in pretest scores, posttest, and follow-up used paired sample T-test in the experimental group and the control group. The results of data analysis used Paired Sample T-Test on the pretestposttest scores showed $t=-23.884$ with a significance level $=0.000$ $(p<0.005)$, the results of the analysis on the posttest-follow-up
\end{abstract}


scores showed $t=4,481$ with a significance level $=0.000(p<$ $0.005)$, and the results of the analysis on the pretest score-followup showed $t=-20821$ with a significance level $=0.000(p<0.005)$. The results of this analysis showed that the experimental group treated with increased motivation to learn after being given the training goal setting than before given the goal setting training.

\begin{abstract}
Abstrak
Penelitian ini bertujuan untuk mengetahui pengaruh pelatihan goal setting untuk meningkatkan motivasi belajar pada mahasiswa. Hipotesis dalam penelitian ini adalah ada perbedaan tingkat motivasi belajar mahasiswa antara Kelompok Eksperimen dengan Kelompok Kontrol sebelum dan sesudah diberi pelatihan goal setting. Mahasiswa yang diberi pelatihan goal setting (Kelompok Eksperimen) akan mengalami peningkatan motivasi belajarnya setelah diberi perlakuan pelatihan Goal Setting daripada mahasiswa yang tidak diberi pelatihan goal setting (Kelompok Kontrol). Subjek dalam penelitian ini berjumlah delapanbelas orang untuk kelompok eksperimen dan delapanbelas orang untuk kelompok kontrol. Alat ukur yang digunakan untuk mengukur tingkat motivasi belajar adalah skala motivasi belajar. Rancangan eksperimen yang digunakan dalam penelitian ini yaitu Pre-Test Post-Test Control Group Design dan proses penentuan subjek dilakukan secara random. Analisis yang digunakan adalah uji statistik parametrik model Independent Sample T-Test untuk melihat perbedaan skor motivasi belajar antara kelompok eksperimen dengan kelompok kontrol. Hasil analisis data pretest menggunakan Independent Sample T-Test diketahui nilai sig $=0.798(\mathrm{p}>0.05)$ dan analisis data posttest diketahui nilai sig $=0.000(\mathrm{p}<0.005)$. Sedangkan untuk melihat perbedaan skor pretest, posttest dan followup menggunakan Paired Sample T-Test pada kelompok eksperimen dan kelompok kontrol. Hasil analisis data menggunakan Paired Sample T-Test pada skor pretest-posttest menunjukkan $t=-23,884$ dengan taraf signifikansi $=0.000(\mathrm{p}<0.005)$, hasil analisis pada skor posttestfollowup menunjukkan $t=4.481$ dengan taraf signifikansi $=0.000$ $(\mathrm{p}<0.005)$, serta hasil analisis pada skor pretest-followup menunjukkan $t=-20.821$ dengan taraf signifikansi $=0.000$ $(\mathrm{p}<0.005)$. Hasil analisis ini menunjukkan bahwa kelompok eksperimen yang diberi perlakuan mengalami peningkatan motivasi belajar setelah diberi pelatihan goal setting dibandingkan sebelum diberi pelatihan goal setting.
\end{abstract}

Keyword: goal setting training, learning motivation 


\section{Pendahuluan}

Mahasiswa sebagai manusia ilmiah diharapkan mampu menjadi sumber daya yang dapat menciptakan keharmonisan dan kedinamisan pembangunan bangsa. Untuk mewujudkan hal tersebut, maka seorang mahasiswa harus memiliki keahlian dan kreativitas yang tinggi sehingga setelah lulus atau meraih gelar kesarjanaan, mahasiswa benar-benar mampu menjadi manusia berkualitas yang dapat mengaplikasikan ilmu yang diperoleh selama kuliah dalam lingkungan yang lebih luas yaitu lingkungan sosial masyarakat. Kendatipun demikian, untuk mencapai keberhasilan diperlukan usaha yang kuat dan keras, tidak sedikit hambatan dalam mencapai dan mempertahankan kinerja akademik mahasiswa.

Salah satu faktor yang berperan dalam pencapaian prestasi terutama bagi mahasiswa dalam bidang akademik adalah motivasi yang dimiliki mahasiswa tersebut. Tinggi ataupun rendah motivasi yang dimiliki seorang mahasiswa ikut menentukan tercapai atau tidaknya prestasi dalam kelas, meskipun intelegensi maupun bakat dan minat merupakan modal dasar bagi mahasiswa dalam pencapaian prestasi akademik (Syafitri, 2004). Penelitian yang dilakukan oleh Morisano, dkk (2010) mahasiswa yang mendaftar di Mc.Gill University Montreal Quebec Canada, 25\% tidak pernah menyelesaikan studinya, penyebabnya adalah perkembangan akademis yang buruk dan motivasi belajar yang rendah.

Menurut Akhter, dkk (2011), motivasi dapat menstimulasi, mempertahankan serta memberi arah pada setiap individu untuk melakukan suatu aktivitas. Walgito (2003), menyatakan bahwa motivasi merupakan keadaan dalam individu atau organisme yang 
mendorong perilaku ke arah tujuan. Menurut Santrock (2007), motivasi adalah proses yang memberi semangat, arah, dan kegigihan perilaku, artinya perilaku yang termotivasi adalah perilaku yang penuh energi, terarah, dan bertahan lama. Winkel (1996) menyatakan bahwa motivasi belajar adalah keseluruhan daya penggerak di dalam diri siswa yang menimbulkan kegiatan belajar, sehingga tujuan yang dikehendaki siswa tercapai.

Berdasarkan hasil wawancara awal dengan 10 orang mahasiswa di salah satu Perguruan Tinggi X di Lampung yang berinisial D, A, S, F, G, E, T, A, M, A pada tanggal 29, 30, dan Juli 2013 menunjukkan ciri-ciri motivasi belajar yang rendah sesuai karakteristik motivasi belajar menurut Sardiman (2001): (1) tidak adanya keinginan atau inisiatif untuk belajar, bentuk perilakunya berdasarkan hasil wawancara dengan semua subjek adalah para mahasiswa cenderung malas belajar, tidak intensif belajar, frekuensi belajar sehari-hari yang kurang, sering tidak mengikuti perkuliahan, malas mengerjakan tugas kelompok, (2) tidak adanya arah dalam belajar, bentuk perilakunya berdasarkan hasil wawancara dengan semua subjek adalah para mahasiswa belajar dengan pola yang tidak teratur, seperti ada istilah belajar (sistem kebut semalam), belajar hanya pada saat-saat tertentu, (3) tidak adanya konsistensi atau keajegan, bentuk perilakunya berdasarkan hasil wawancara dengan semua subjek adalah para mahasiswa dalam melakukan proses belajar, sering melakukan aktivitas lain seperti kegiatan yang menyenangkan seperti bermain, internetan, menonton TV, dan lain-lain.

Karakteristik motivasi belajar yang rendah pada mahasiswa yang dijelaskan di atas diperjelas lagi berdasarkan keterangan dosen yang berinisial IP yang mengajar di PT tersebut, dosen I menjelaskan 
bahwa para mahasiswa memiliki motivasi untuk belajar yang rendah, saat diberikan materi di kelas, banyak mahasiswa yang tidak fokus pada materi kuliah malah asyik mengobrol, bermain HP, hasil nilai pada saat quiz ataupun ujian juga rendah sehingga mereka sering remidial untuk mengulang mata kuliah yang nilainya kurang tersebut. Lebih lanjut dijelaskan oleh dosen IP, ketika ujian berlangsung, para mahasiswa masih saja melakukan kegiatan mencontek satu sama lain, bahkan setelah beberapa kali diingatkan oleh dosen dan pengawas ujian. Saat praktik pada mata kuliah tertentu, banyak mahasiswa yang tidak bisa melakukan materi praktik padahal sudah dijelaskan di kelas oleh dosen.

Menurut dosen berinisial SR, para mahasiswa cenderung sering malas-malasan dalam proses belajar mengajar sehingga mengakibatkan para mahasiswa tersebut kurang menguasai keahlian/kompetensi yang harus dilaksanakan di lokasi tempat praktik mahasiswa, hal tersebut sering menjadi evaluasi para supervisor lapangan ditempat praktik para mahasiswa dan menimbulkan efek kurang positif terhadap institusi. Para mahasiswa dari perguruan tinggi $\mathrm{X}$ tersebut sering dianggap kurang kompeten, namun para mahasiswa tidak jarang menyalahkan pihak pengajar, dengan alasan materi praktik yang belum diajarkan kepada mahasiswa, padahal materi praktik tersebut sudah diajarkan, tetapi para mahasiswa tersebut yang tidak memperhatikan materi sehingga tidak menguasai. Masih berdasarkan penjelasan SR, para mahasiswa yang kurang motivasi belajarnya tersebut seperti tidak mempunyai tujuan untuk menguasai materi praktik dan menjadi profesional di bidangnya tersebut. 
Berdasarkan hasil wawancara awal tersebut dapat diketahui bahwa motivasi belajar pada beberapa mahasiswa di PT X tersebut tergolong rendah dikarenakan mahasiswa masih belum memiliki tujuan yang jelas dalam menjalani kuliah. Para mahasiswa yang menjalani studi di perguruan tinggi $\mathrm{X}$ tersebut merupakan calon professional dalam bidangnya, sehingga dibutuhkan kompetensi yang baik.

Motivasi belajar rendah yang ditunjukkan mahasiswa di perguruan tinggi $\mathrm{X}$ tersebut merupakan bentuk dari kurang jelasnya tujuan belajar yang ingin dicapai mahasiswa, jika mahasiswa tersebut sudah jelas tujuan yang ingin dicapai maka dia akan meraih tujuan tersebut dengan motivasi belajar yang tinggi.

Tuan, dkk (2005) mengemukakan bahwa dalam proses pembelajaran, hal yang berpengaruh pada motivasi belajar yaitu: tujuan belajar, strategi belajar dan lingkungan belajar yang merangsang siswa mengembangkan pemikiran ilmiahnya, faktorfaktor tersebut mewakili pengaruh yang bekerja baik dari luar dan dari dalam diri siswa. Dalam penelitian ini, faktor penetapan tujuan menjadi perhatian penulis karena penetapan tujuan yang baik dapat membantu para mahasiswa yang memiliki motivasi belajar yang rendah untuk mencapai tujuan belajar yang diharapkan.

Secara umum terdapat beberapa teknik intervensi untuk meningkatkan motivasi belajar, misalnya pelatihan berfikir positif (Fitri, 2007), penerapan strategi Think-Pair-Share (Hernawati, 2012), melalui metode pembelajaran yang menyenangkan/ Joyful Learning (Salam, 2012), metode konseling kelompok (Suseno, 2013), serta pelatihan goal setting (Puspita, 2012). 
Selanjutnya pada penelitian ini peneliti mencoba untuk mengemas sebuah intervensi pelatihan penetapan tujuan (goal setting) untuk meningkatkan motivasi belajar pada mahasiswa. Menurut Locke (Yearta, Maitlis, dan Briner, 1995) goal setting adalah sebuah teori kognitif dengan dasar pemikiran bahwa setiap orang memiliki suatu keinginan untuk mencapai hasil spesifik atau tujuan yang diharapkan dapat tercapai.

Penerapan pelatihan goal setting ini sesuai dengan pendapat Locke dan Latham (1990) yang menyebutkan bahwa tidak adanya penetapan tujuan belajar akan membuahkan motivasi dan hasil belajar yang rendah. Berdasarkan pendapat Locke, dkk, (1981), terdapat lima komponen goal setting, yaitu : (1) kejelasan, (2) tantangan, (3) kompleksitas tugas, (4) komitmen, dan (5) umpan balik. Ke lima komponen tersebut merupakan dasar dalam pembuatan modul pelatihan goal setting yang akan diberikan kepada mahasiswa untuk meningkatkan motivasi belajarnya. Penetapan tujuan dapat menjadi daya dorong untuk memperbesar usaha yang dilakukan seseorang, bahwa seseorang akan bekerja lebih keras dengan adanya tujuan daripada tanpa tujuan (Locke, dkk, 1981).

Penetapan tujuan (goal setting) menjadi hal yang penting diperhatikan untuk meningkatkan motivasi belajar mahasiswa, hal tersebut diperkuat oleh penelitian yang dilakukan Kativasalampi, dkk (2009) yang menunjukkan bahwa siswa yang memiliki tujuan yang jelas terhadap pendidikannya cenderung mempunyai minat terhadap pendidikannya dan memiliki motivasi belajar yang tinggi, sebaliknya siswa yang tidak memiliki tujuan yang jelas terhadap pendidikannya 
cenderung tidak memiliki minat terhadap pendidikannya dan memiliki motivasi belajar yang rendah.

Melalui pelatihan goal setting diharapkan mahasiswa dapat mempunyai tujuan yang jelas sehingga mampu menyelesaikan tugas akademik. Setelah materi dan kemampuan diberikan melalui pelatihan goal setting, diasumsikan akan terjadi peningkatan motivasi belajar peserta pelatihan.

Berdasarkan penjelasan teoritis dan hasil-hasil penelitian di atas mengenai permasalahan dalam penelitian ini, maka peneliti mengajukan hipotesis penelitian sebagai berikut: "Ada perbedaan tingkat motivasi belajar mahasiswa antara Kelompok Eksperimen dengan Kelompok Kontrol sebelum dan sesudah diberi pelatihan goal setting. Mahasiswa yang diberi pelatihan goal setting (Kelompok Eksperimen) akan mengalami peningkatan motivasi belajarnya setelah diberi perlakuan pelatihan Goal Setting daripada mahasiswa yang tidak diberi pelatihan goal setting (Kelompok Kontrol)"

\section{Metode Penelitian}

Penelitian ini dilakukan dengan menggunakan desain eksperimen pretest-postest control group designs. Dalam desain ini kelompok subjek akan dibagi dua dan akan mendapat pengukuran sebelum dan sesudah pemberian perlakuan/manipulasi (Azwar, 2005). Pretest-posttest adalah pengukuran yang dilakukan secara berulang, pada pra dan paska diberikannya manipulasi. Kelompok kontrol adalah yang tidak diberi manipulasi berupa pelatihan. Kelompok eksperimen adalah kelompok yang diberi manipulasi berupa pelatihan Goal Setting.

Desain Penelitian

\begin{tabular}{ccccc}
\hline & $\mathrm{KE}$ & $\mathrm{O}_{1}$ & $\mathrm{X}$ & $\mathrm{O}_{2}$ \\
$\mathrm{R}$ & & $\mathrm{O}_{3}$ & & \\
\cline { 2 - 5 } & $\mathrm{KK}$ & $\mathrm{O}_{1}$ & -- & $\mathrm{O}_{2}$ \\
\hline
\end{tabular}


Keterangan: --

KE: Kelompok Eksperimen (kelompok yang mendapat perlakuan)

KK: Kelompok Kontrol (kelompok yang tidak mendapat perlakuan)

\section{$\mathrm{R}$ : Random Assignment}

$\mathrm{X}$ : Pemberian manipulasi/perlakuan

-- : Tanpa manipulasi/perlakuan

$\mathrm{O}_{1}$ : Pengukuran variabel dependen sebelum manipulasi (pre-test)

$\mathrm{O}_{2}$ : Pengukuran variabel dependen setelah manipulasi (post-test)

$\mathrm{O}_{3}$ : Follow $U p$

Perlakuan diberikan dalam bentuk pelatihan goal setting, yang dikenakan pada kelompok eksperimen. Metode pelatihan dipilih karena merupakan media yang dinilai efektif untuk mentransfer pengetahuan (Noe, 2002). Modul pelatihan disusun oleh peneliti dengan menggabungkan beberapa metode, yaitu ceramah, permainan, mengerjakan lembar kegiatan, dan diskusi.

Pelatihan goal setting ini bertujuan untuk memperkenalkan subjek penelitian tentang goal setting, dan bagaimana menerapkan goal setting dalam meningkatkan motivasi belajar. Pelatihan ini dipandu oleh seorang trainer yaitu seorang psikolog yang bekerja sebagai Dosen di salah satu Universitas Swasta di Lampung, memiliki kemampuan interpersonal yang baik, aktif mengikuti kegiatan pelatihan, serta memiliki beberapa kualifikasi ketrampilan sebagai konselor antara lain hangat, penuh penerimaan, dan empatik. Satu orang ko-trainer, ko-trainer adalah salah satu dosen di Perguruan Tinggi $\mathrm{X}$ di Lampung yang telah berpengalaman dalam beberapa pelatihan, memiliki kemampuan interpersonal yang baik, serta 
memiliki kualifikasi ketrampilan sebagai konselor antara lain hangat, penuh penerimaan, dan empatik. Dua orang observer, observer adalah sarjana psikologi yang telah lulus mata kuliah observasi, pernah mengikuti kegiatan pelatihan sebelumnya

Subjek penelitian adalah mahasiswa pada sebuah Perguruan Tinggi Swasta di Lampung. Subjek ditentukan berdasarkan kriteria sebagai berikut: (1) mahasiswa aktif di Perguruan Tinggi X, (2) memiliki motivasi belajar yang rendah, (3) belum pernah mengikuti pelatihan goal setting.

Metode pengukuran yang digunakan dalam penelitian adalah dengan menggunakan skala motivasi belajar. Dasar pengambilan metode pengukuran menggunakan skala adalah bahwa skala merupakan alat ukur yang digunakan untuk mengukur aspek psikologi (Azwar, 2005).

Variabel dependen dalam penelitian ini adalah motivasi belajar. Alat ukur yang digunakan untuk mengukur motivasi belajar adalah skala motivasi belajar yang dibuat peneliti mengacu pada karakteristik motivasi belajar yang diungkapkan oleh Sardiman (2001) yaitu: keinginan atau inisiatif untuk belajar, adanya arah dalam belajar, dan adanya konsistensi atau keajegan.

Berikut ini tahapan pelatihan goal setting dalam penelitian ini, berdasarkan urutan sesi per sesi (sequency) modul pelatihan goal setting yang telah dilakukan sebelumnya oleh Puspita (2012), tahapan ini mengacu pada komponen goal setting menurut Locke (1981), diantaranya adalah:

1. Sesi I : Pembukaan

Tujuan sesi ini adalah mencairkan suasana pelatihan serta saling mengenal antara anggota kelompok dan tariner sehingga dapat 
menumbuhkan suasana akrab antar peserta dan trainer, ko-trainer, dan peserta saling memperkenalkan diri melalui media permainan.

2. Sesi II : "My Inspiration"

Tujuan sesi ini adalah peserta dapat membuat tujuan yang spesifik, dengan tujuan spesifik dan difenisikan lebih mungkin untuk berhasil dalam hidup daripada mereka yang tidak, agar inspirasi kepribadian orang sukses membantu peserta secara sistematis untuk merumuskan tujuan mereka menggunakan pendekatan ini.

3. Sesi III : "Aku Yakin Bisa"

Tujuan sesi ini adalah peserta bisa menetapkan tujuan yang menantang namun dapat dicapai, untuk meningkatkan kemampuan diri, peserta dapat memastikan sudah menggunakan potensi yang dimilikinya secara maksimal.

\section{Sesi IV : "Semua Terasa Mudah"}

Tujuan sesi ini adalah peserta dapat membuat tujuan yang mudah dipahami, peserta realistis dalam menetapkan tujuan, sehingga usahanya tidak sia-sia.

5. Sesi V : "Selalu Konsisten"

Tujuan sesi ini adalah peserta dapat berkomitmen pada tujuan yang dibuat, peserta tetap gigih pada tujuannya, tidak mudah berubah dengan pengaruh dan tantangan dari dalam maupun dari luar diri.

6. Sesi VI : "Kuraih Targetku"

Tujuan sesi ini adalah peserta dapat memanfaatkan umpan balik dari pekerjaan yang dilakukan..

7. Sesi VII : Penutup dan Evaluasi 
Tujuan sesi ini adalah wawasan dan kemampuan menetapkan tujuan peserta meningkat. Pada sesi ini juga trainer menutup pelatihan serta memberikan setifikat pelatihan.

Metode analisis data yang digunakan dalam penelitian ini adalah dengan menggunakan metode kuantitatif yang dilakukan adalah dengan menggunakan Uji Parametrik. Untuk menguji perbedaan skor skala motivasi belajar antara kelompok eksperimen dan kelompok kontrol sebelum (Pretest) dan setelah (Posttest) pelatihan digunakan uji statistik Independent Sample t-test. Sedangkan untuk menganalisis perbedaan skor pretest dengan posttest dengan follow up pada kelompok eksperimen digunakan Uji Paired Sample t-test. Proses analisis datanya menggunakan program SPSS versi 16.

\section{Hasil dan Pembahasan}

Untuk menguji hipotesis, dilakukan uji perbedaan nyata antara kelompok eksperimen dan kelompok kontrol setelah kelompok eksperimen diberi perlakuan dengan menggunakan Uji Independent Sample t-test. Hipotesis yang diajukan adalah mahasiswa yang diberi pelatihan goal setting (Kelompok Eksperimen) akan mengalami peningkatan motivasi belajarnya setelah diberi perlakuan pelatihan Goal Setting daripada mahasiswa yang tidak diberi pelatihan goal setting (Kelompok Kontrol).

Hasil analisis Independent Sample T-Test antara Kelompok Eksperimen dengan Kelompok Kontrol. Hasil uji beda pada saat pretest ditemukan nilai t sebesar -0,259 dengan sig (2-tailed) sebesar 0,798 ( $\mathrm{p}>0,05)$. Hasil analisis menunjukkan bahwa tidak ada perbedaan antara kelompok eksperimen dan kelompok kontrol. Pada skor posttest ditemukan nilai $t$ sebesar 11,346 dengan sig (2-tailed) sebesar 0,000 $(\mathrm{p}<0,05)$. Hasil analisis ini menunjukkan bahwa setelah 
kelompok eksperimen diberi perlakuan, tingkat motivasi belajar mengalami perbedaan yaitu motivasi belajar kelompok eksperimen mengalami peningkatan signifikan dibandingkan pada kelompok kontrol.

Hasil analisis Paired Sample T-Test pada Kelompok Eksperimen dan Kelompok Kontrol. Selain menggunakan uji parametrik dengan teknik Uji Independent Sample t-test dalam melihat perbedaan antara kelompok eksperimen dan kelompok kontrol, dalam penelitian ini juga menggunakan uji Paired Sample ttest. Hal ini bertujuan untuk melihat apakah ada perbedaan antara skor pretest dan posttest serta followup pada kelompok eksperimen.

Hasil uji Paired sample T-Test pada kelompok eksperimen menunjukkan adanya signifikansi antara pretest dan posttest, dapat dilihat dari diperolehnya nilai $t$-test sebesar $-23,844$ dengan taraf $s i g=$ 0.000 ( $\mathrm{p}<0.005)$. Hal tersebut berarti ada perbedaan antara sebelum pemberian pelatihan Goal Setting dan setelahnya. Selain melihat perbedaan skor pretest dan posttest pada kelompok eksperimen, hal yang sama juga dilakukan pada kelompok kontrol. Hasil yang diperoleh dari uji Paired Sample t-test pada kelompok kontrol adalah nilai t-test sebesar $-3,381$ dengan taraf sig $=0.004(\mathrm{p}<0.005)$, hal ini juga menunjukkan terdapat perbedaan skor antara pretest dan posttest pada kelompok kontrol.

Berdasarkan hasil uji Paired Sample t-test yang dilakukan pada kelompok eksperimen dan kelompok kontrol ditemukan bahwa terjadi peningkatan skor yang signifikan pada kelompok eksperimen, hal ini dapat dilihat dari rerata (mean) pretest dan posttest kelompok eksperimen yaitu terjadi peningkatan sebesar 83 poin. Pada kelompok 
kontrol juga terdapat perubahan rerata (mean) pretest dan posttest tetapi perubahan tersebut tidak signifikan, hanya terjadi peningkatan 16 poin, jika dibandingkan dengan kelompok eksperimen yang meningkat 83 poin, maka pada kelompok kontrol perubahan rerata tersebut bisa dikarenakan pada hal lain selain perlakuan, dan pada kelompok eksperimen dapat dikatakan bahwa pelatihan goal setting yang diberikan kepada kelompok eksperimen bisa dikatakan efektif dalam meningkatkan motivasi belajar pada mahasiswa.

Pada kelompok eksperimen juga dilakukan analisis pada saat setelah perlakuan (posttest) dengan pengukuran ulang (followup), dengan hasil t-test sebesar 4.481 dengan taraf $\operatorname{sig}=0.000(\mathrm{p}<0.005)$, berdasarkan hasil analisis tersebut berarti juga terdapat perbedaan skor antara setelah perlakuan (posttest) dengan pengukuran ulang (followup), perbedaan tersebut terlihat juga pada rerata (mean) yang terjadi penurunan sebesar 14 poin, penurunan skor rerata pada kelompok eksperimen setelah diukur ulang (followup) mengindikasikan bahwa terdapat penurunan motivasi belajar pada beberapa subjek pada kelompok eksperimen. Selanjutnya untuk mengetahui apakah terdapat perbedaan antara sebelum perlakuan (pretest) dengan proses pengukuran ulang (followup), dilakukan uji paired sample t-test dengan hasil $t$-test sebesar -20.281 dengan sig $=$ $0.000(\mathrm{p}<0.005)$, hal tersebut berarti terdapat perbedaan antara pretest dengan followup, terdapat peningkatan rerata yang cukup besar antara pretest dengan followup yaitu sebesar 68 poin. Hal ini mengindikasikan bahwa meskipun beberapa subjek mengalami penurunan skor saat followup dibandingkan dengan saat posttest tetapi penurunan tersebut masih lebih tinggi dari skor pada saat pretest.

Berdasarkan hasil analisis terhadap uji hipotesis, diketahui bahwa terdapat perbedaan motivasi belajar mahasiswa pada kelompok eksperimen sebelum perlakuan (pretest) dan setelah perlakuan (posttest) berupa pelatihan goal setting dibanding 
Kelompok Kontrol yang tidak diberi perlakuan berupa pelatihan goal setting.

Diketahui bahwa pada saat pengukuran setelah perlakuan (posttest), tingkat motivasi belajar pada kelompok eksperimen setelah mendapat pelatihan goal setting mengalami peningkatan motivasi belajar yang signifikan pada 18 orang subjek. Ada tujuhbelas orang subjek pada saat pretest memiliki skor dalam kategori rendah, tetapi setelah posttest subjek tersebut mengalami peningkatan motivasi belajar menjadi kategori tinggi. Sementara terdapat satu orang subjek saat pretest memiliki skor dalam kategori rendah, tetapi setelah posttest subjek tersebut mengalami peningkatan motivasi belajar menjadi kategori sedang. Para subjek kelompok eksperimen yang diberi pelatihan Goal Setting mengalami peningkatan motivasi belajar, hal ini dapat dilihat dari hasil rerata (mean) pada kelompok eksperimen menunjukkan peningkatan skor yang signifikan sebesar 83 poin dari sebelum perlakuan (pretest) hingga setelah perlakuan (posttest) dengan nilai Sig $=0,000 \quad(\mathrm{p}<0,05)$. Nilai tersebut membuktikan bahwa terjadi peningkatan yang signifikan pada skor subjek kelompok eksperimen pada sebelum perlakuan (pretest) dan setelah perlakuan (posttest) sehingga hipotesis yang diajukan peneliti bahwa pelatihan Goal Setting dapat meningkatkan motivasi belajar pada mahasiswa dapat diterima.

Peneliti juga melakukan analisis pada kelompok eksperimen dengan membandingkan skor skala antara sesudah perlakuan (posttest) dengan pengukuran ulang (followup), serta antara sebelum perlakuan (pretest) dengan saat pengukuran ulang (followup). Berdasarkan hasil analisis Paired Sample T-Test diperoleh hasil 
perbedaan antara posttest dengan followup hasilnya adalah sig = $0.000(\mathrm{p}<0.005)$, hal ini menandakan adanya perbedaan antara skor posttest-followup. Berdasarkan perolehan skor dan hasil analisis pada tabel 4.4 diketahui bahwa pada saat follow up yaitu pengukuran ulang setelah 6 hari mendapatkan perlakuan pelatihan goal setting diketahui subjek kelompok eksperimen mengalami perubahan pada empat subjek, yaitu mengalami perubahan skor dan kategori dari tinggi menjadi sedang, sementara empat belas subjek yang lain mengalami perubahan skor tetapi tidak berubah kategorinya yaitu tetap pada kategori tinggi. Pada hasil rerata (mean) posttest kelompok eksperimen mengalami penurunan sebesar 14 poin pada saat pengukuran ulang (followup), hal ini mengindikasikan bahwa pada beberapa subjek yang mengalami penurunan skor skala saat followup, bisa dikarenakan karena subjek tersebut dalam kondisi motivasi yang tidak setinggi pada saat posttest. Beberapa faktor yang dapat mempengaruhi motivasi belajar subjek yang menurun tersebut, seperti yang diterangkan oleh Lashley (dalam Chauhan, 1978) adalah: faktor fisiologis, faktor emosi, kebiasaan yang dapat menjadi motivator, faktor mental set, nilai dan sikap individu, dan faktor lingkungan dan insentif.

Berdasarkan hasil analisis Paired Sample T-Test diperoleh hasil perbedaan antara prettest dengan followup hasilnya adalah sig = 0.000 ( $\mathrm{p}<0.005)$, hal ini menandakan adanya perbedaan antara skor pretest dengan followup. Pada hasil rerata (mean) pretest kelompok eksperimen mengalami peningkatan sebesar 68 poin dibandingkan dengan hasil rerata (mean) followup, hal ini mengindikasikan bahwa meskipun terdapat penurunan rerata skor followup dibanding dengan rerata skor posttest, tetapi tetap terjadi peningkatan skor rerata 
followup dibanding skor rerata pretest. Hasil tersebut menunjukkan bahwa kondisi para subjek yang mengalami penurunan skor saat followup tidak kembali ke kondisi awal sebelum perlakuan (pretest), hal ini berarti kondisi subjek yang mengalami penurunan skor skala motivasi belajar bisa dikarenakan faktor selain karena perlakuan pelatihan goal setting, karena para subjek yang mengalami penurunan skor saat followup, masih dalam kategori tingkat motivasi tinggi dan sedang, tidak kembali ke kategori rendah seperti kondisi sebelum perlakuan pelatihan goal setting.

Pada kelompok kontrol diketahui bahwa terjadi perubahan skor pada beberapa subjek, diantaranya peningkatan kategori dari rendah ke sedang sebanyak tujuh orang subjek, terdapat tiga orang subjek yang mengalami penurunan skor tetapi masih dalam kategori motivasi rendah, serta delapan orang subjek yang mengalami peningkatan skor tetapi masih dalam kategori motivasi rendah. Hasil analisis menggunakan Paired Sample T-Test pada kelompok kontrol diperoleh sig $=0.004(\mathrm{p}<0.005)$, hal ini berarti terdapat perbedaan antara skor pretest dengan posttest kelompok kontrol. Perbedaan yang ditandai dengan perolehan hasil analisis pada kelompok kontrol mengindikasikan adanya perubahan tingkat motivasi belajar pada kelompok kontrol, hal ini dapat diketahui juga dengan melihat rerata (mean) pada saat pretest dan posttest yang mengalami peningkatan sebesar 16 poin. Terjadinya peningkatan rerata (mean) pada kelompok kontrol ini bisa terjadi karena beberapa faktor selain adanya pengaruh perlakuan, diantaranya yang peneliti temukan adalah pada saat pemberian pengukuran ulang (posttest) kepada kelompok kontrol, dilaksanakan pada saat Ujian Akhir Semester 
(UAS), hal ini bisa berdampak pada motivasi belajar subjek kelompok kontrol yang mengalami peningkatan skor. Subjek mempunyai kebutuhan untuk mencapai hasil belajar sebaik mungkin saat Ujian Akhir Semester (UAS), sehingga motivasi belajarnya naik, hal ini sesuai dengan pendapat Sardiman (2001), yang menyatakan bahwa motivasi belajar dipengaruhi oleh kebutuhan untuk mencapai hasil belajar.

Berdasarkan pernyataan para subjek kelompok eksperimen, maka dapat disimpulkan bahwa setelah mendapatkan pelatihan Goal Setting, subjek merasakan mendapatkan motivasi untuk belajar, merencanakan pola belajar setiap hari, lebih fokus terhadap kuliah, dan menentukan tujuan kuliah, diantaranya mendapatkan; IPK yang baik, menguasai materi kuliah, dan lulus dengan hasil baik. Hal ini sesuai dengan pendapat Robin (1989) yang menyatakan bahwa penetapan tujuan (Goal Setting) mempengaruhi proses belajar dengan cara mengarahkan perhatian dan tindakan, memobilisasi pengerahan usaha, memperpanjang lamanya pengerahan usaha, dan memotivasi individu untuk mengembangkan strategi yang relevan untuk mencapai tujuannya.

Pelatihan Goal Setting ini diberikan oleh seorang psikolog yang berpengalaman dalam bidang training dan juga merupakan seorang dosen. Selama pelatihan para peserta terlihat antusias dan semangat dalam mengikuti sesi demi sesi pelatihan hingga sesi terakhir yaitu sesi evaluasi dan penutupan pelatihan. Dalam pelatihan ini para peserta terlibat aktif dalam permainan, disikusi, dan presentasi yang dilakukan.

Berdasarkan uraian di atas dapat ditarik kesimpulan secara menyeluruh bahwa pelatihan goal setting dapat meningkatkan 
motivasi belajar mahasiswa yang memiliki motivasi belajar yang rendah.

\section{Simpulan dan Saran}

Hasil penelitian ini membuktikan bahwa terdapat perbedaan tingkat motivasi belajar mahasiswa sebelum dan setelah diberi pelatihan goal setting. Mahasiswa yang diberi pelatihan goal setting memiliki motivasi belajar yang tinggi setelah diberi pelatihan goal setting dibandingkan dengan mahasiswa yang tidak diberi pelatihan goal setting. Sebelum mendapat pelatihan Goal Setting, semua subjek kelompok eksperimen sejumlah 18 orang masuk dalam kategori motivasi belajar rendah. Setelah diberi pelatihan Goal Setting terdapat 17 orang subjek mengalami peningkatan motivasi pada kategori tinggi, dan satu orang subjek pada kategori sedang.

Hasil analisis menggunakan teknik Independent sample $T$ Test menunjukkan perbedaan antara kelompok eksperimen yang diberi pelatihan dengan kelompok kontrol yang tidak diberi pelatihan. Hasil analisis menggunakan teknik Paired Sample T-Test pada kelompok eksperimen menunjukkan bahwa pelatihan Goal Setting berpengaruh untuk meningkatkan motivasi belajar pada mahasiswa.

\section{Referensi}

Azwar, S. (2005). Metode Penelitian. Yogyakarta: Pustaka Pelajar.

Chauhan, S. (1978). Advance Educational Psychology. Third Edition. New Delhi: Vikes Publishing House.

Hardjana, A. (2003). Training SDM yang Efektif. Yogyakarta: Kanisius

Locke, E., Shaw, K., Saari, L., \& Latham, G. (1981). Goal Setting and task performance: 1969-1980. Psychology Bulleti. (90), 125-152. 
Noe, R. (2002). Employee training and development. New York: MacGraw-Hill.

Puspita, Y. (2012). Pelatihan Goal Setting untuk Meningkatkan Motivasi Belajar Pada Siswa SMK. Tesis. (tidak diterbitkan). Yogyakarta: Fakultas Psikologi Universitas Gadjah Mada.

Santrock, J. (2002). Life Span Development. (terjemahan). Jakarta: Erlangga.

Sardiman, A. (2001). Interaksi dan Motivasi Belajar Mengajar Pedoman Bagi Guru dan Calon Guru. Jakarta: Raja Grafindo Persada.

Syafitri, A. (2004). Gambaran aspek-aspek yang mempengaruhi prestasi akademik pada siswa SMUN 106 Jaarta yang berprestasi akademik rendah. Jurnal Psikodinamik, 6, 39-57.

Syah, M. (2004). Psikologi Pendidikan dengan Pendekatan Baru. Bandung: Rosdakarya

Yearta, S., Maitlis, S., \& Briner, R. (1995). An exploratory study of goal setting in theory and practice: A motivational technique that works. Journal of Occupational and Organizational Psychology, (68), 237-252. 